\title{
Are Ascaris lumbricoides and Ascaris suum a single species?
}

\author{
Daniela Leles ${ }^{1}$, Scott L Gardner², Karl Reinhard ${ }^{3}$, Alena Iñiguez ${ }^{4}$ and Adauto Araujo ${ }^{5^{*}}$
}

\begin{abstract}
Since the original description and naming of Ascaris lumbricoides from humans by Linnaeus in 1758 and later of Ascaris suum from pigs by Goeze 1782, these species have been considered to be valid. Four hypotheses relative to the conspecificity or lack thereof (and thus origin of these species) are possible: 1) Ascaris lumbricoides (usually infecting humans) and Ascaris suum (recorded mostly from pigs) are both valid species, with the two species originating via a speciation event from a common ancestor sometime before the domestication of pigs by humans, or 2) Ascaris lumbricoides in humans is derived directly from the species A. suum found in pigs with A. suum then existing as a persistent ancestor after formation of A. lumbricoides, or 3) Ascaris suum is derived directly from A. lumbricoides with the persistent ancestor being A. lumbricoides and A. suum being the newly derived species, and finally, 4) Ascaris lumbricoides and A. suum are the same species, this hypothesis being supported by studies showing both low morphological and low genetic divergence at several genes. We present and discuss paleoparasitological and genetic evidence that complement new data to evaluate the origin and evolution of Ascaris spp. in humans and pigs, and the uniqueness of the species in both hosts. Finally, we conclude that Ascaris lumbricoides and $A$. suum are a single species and that the name A. lumbricoides Linnaeus 1758 has taxonomic priority; therefore A. suum Goeze 1782 should be considered a synonym of A. lumbricoides.
\end{abstract}

Keywords: Ascaris, coprolites, host-parasite evolution, paleoparasitology, parasitism, helminthiasis

\section{Review}

Metazoan parasites of the order Ascaridida (Phylum Nemata: Class Secernentea) are classified into several families that occur in a wide range of hosts world-wide [1]. Mammals, from marsupials to human and nonhuman primates, birds, reptiles, and fishes, serve as common hosts [1-3]. Iguanodont coprolites dated from 100 million years ago were found positive for ascarid eggs [4]. Although found in many different hosts, species in this group are morphologically conservative, with little variation among groups [5].

Ascaris lumbricoides Linnaeus 1758 is a parasite of Homo sapiens, and Ascaris suum Goeze 1782 occurs in pigs (Sus scrofa Linnaeus 1758). These two ascarids were probably recognized by humans since prehistory, due to their abundance, adult size, symptoms, and distribution. Eggs are commonly found in coprolites, intestinal

\footnotetext{
* Correspondence: adauto@ensp.fiocruz.br

${ }^{5}$ Escola Nacional de Saúde Pública, Fundação Oswaldo Cruz, Rua Leopoldo Bulhões 1480, Manguinhos, Rio de Janeiro, 21041-210, RJ, Brazil Full list of author information is available at the end of the article
}

contents of mummies, and in other kind of archaeological material [6]. Because of their remarkable similarity, several hypotheses have been proposed to explain their origin in their respective hosts. 1) The first hypothesis would be: Ascaris lumbricoides (usually infecting humans) and Ascaris suum (recorded mostly from pigs) are both valid species. In this case, these two species would have originated via a speciation event from a common ancestor, probably sometime before the domestication of pigs by humans. There are no records of Ascaris from the great apes, so this hypothesis has little support. 2) Ascaris lumbricoides in humans is derived directly from the species $A$. suum found in pigs with $A$. suum then existing as a persistent ancestor. In this case the species A. lumbricoides could have arisen by an allopatric event of host-switching (pig to human). 3) Ascaris suum is derived directly from $A$. lumbricoides with the persistent ancestor being A. lumbricoides and A. suum being the more newly derived species. Exactly the opposite of 2 above. Finally, hypothesis 4) states that: Ascaris lumbricoides and A. suum are conspecific, this hypothesis has
Ciomed Central

(c) 2012 Leles et al; licensee BioMed Central Ltd. This is an Open Access article distributed under the terms of the Creative Commons Attribution License (http://creativecommons.org/licenses/by/2.0), which permits unrestricted use, distribution, and reproduction in any medium, provided the original work is properly cited. 
support from studies showing both low morphological and low genetic divergence (low genetic distances) in several genes. Ascaris lumbricoides is considered a parasite with a relatively long history of association with Homo sapiens $[7,8]$ and up to the present time, neither classical taxonomony or molecular genetics have been able establish whether there is one or two distinct species. However, a particular host affiliation has been proposed [9-11]. Concepts and theories concerning the origin of Ascaris spp. parasitic in human and pig hosts will be briefly reviewed.

\section{Parasitological Evidence}

Probably the main reason for two accepted species, A. lumbricoides and A. suum, was the finding of adult worms in the intestine of two distinct hosts, humans and pigs. The eggs found in fecal material are identical morphologically, but adult worms of the two species have slight differences in morphological characteristics that can be used to distinguish between them [12]. Attempts at experimental infections were successful in establishing the nematodes in pigs with worm eggs collected from humans and vice-versa and the parasite life cycle was completed in both hosts [13-17] ([see [11]]). An accidental laboratory human infection with Ascaris eggs extracted from pigs was also reported [18]. Nevertheless, in another separate experiment Ascaris eggs with the typical human-specific genotype were unable to mature in pigs [19]. It has also been shown that if cross infections from humans to pigs is attempted, it appears that a very heavy infective parasite load is needed to achieve infection in the pig hosts [7]. Therefore, there is still no consensus on infection potential in these two species of Ascaris.

The hypotheses of host switching and subsequent speciation presented above have also been proposed to explain the origin of Trichuris trichiura in humans and Trichuris suis in pigs [20]. However, T. trichiura in humans is now considered a so-called "heirloom species" that is shared by humans and apes and was inherited from a common primate ancestor [21]. Three aspects of the biology of species of Trichuris support this hypothesis [20]: a) Trichuris spp. are found in Old World nonhuman primates, and the most common species are T. lemuris in Lemuroidea, T. cynocephalus and T. presbyticus in Cercopithecoidea, and T. trichiura in Hominoidea. This last parasite was dispersed to other parts of the world via migrations of pre-historic humans; b) parasite ecological adaptations in the host - considering the shorter pre-patent period, egg maturation, and the longer lifespan of T. trichiura adult worms in relation to T. suis, T. trichiura is better adapted to the human host than is $T$. suis to pigs; c) paleoparasitological data showed
T. trichiura eggs in archaeological material of human origin long before pig domestication [6].

When these aspects are examined regarding Ascaris spp. of humans and pigs, the facts generate some degree of controversy. Ascaris species are less diversified in Old World primates compared with Trichuris spp. and, relative to ecological adaptations adult worms of $A$. lumbricoides in humans have a longer lifespan, suggesting a possible better adaptation to humans than A. suum to pigs. However, egg maturation and prepatent periods of $A$. suum in pigs are shorter compared with $A$. lumbricoides in humans

Success in experimental infections or the presence of natural infections in other hosts, such as rodents, dogs, and non-human primates, among others, were recorded both for A. suum and/or A. lumbricoides ([19,22-30] see [11]). There are also records of infections in non-human primates living in natural or similar conditions $[23,26,29]$. In most cases, infection was diagnosed by fecal parasitological analysis, and therefore it was not possible to distinguish between A. suum or A. lumbricoides infection, as it is impossible to distinguish the two species by their eggs (see above). Thus, the origin of Ascaris infection is uncertain where primates are in close contact with wild pigs. South American wild pigs (Tayassu pecari (Link, 1759) and Pecari tajacu (Linnaeus 1758)) were also found infected by Ascaris sp. [31,32]. However, these findings must be suspect, as they may reflect cross-infection from domestic pigs or even humans.

\section{Paleontological, Archaeological and Paleoparasitological Evidence}

The oldest finding of Ascaris spp. eggs in humans was recorded from archaeological material dated 30,000 years before present (BP) [33], many thousands of years before pig domestication at 10,000 years ago [34]. In this study, there was no evidence of pigs in the archaeological context, but the organic sediment was also not clearly confirmed to be of human origin. Samples were collected from a cave inhabited in the past by both modern humans and cave bears, since Ursus spelaeus bone remains were identified. Although modern bears are infected by ascarids, the authors concluded that eggs were of human origin [33]. Therefore, the diagnosis was that of A. lumbricoides eggs based on the archaeological context. Further studies are needed to confirm this extreme antiquity for A. lumbricoides. These findings remain the oldest record for a putative A. lumbricoides human infection. Therefore, more samples should be submitted to paleoparasitological analysis to corroborate these data, and the ancient parasite-host association.

Humans and pigs appeared as species millions of years before the domestication of pigs. The infraorder Suina consists of species allocated to two families, Suidae and 
Tayassuidae. Paleontological evidence suggests that the Suidae diversified by the end of Oligocene (23 million years ago) in Europe, Asia, and Africa, with members of the family Tayassuidae appearing in North and South America by the end of Eocene (34 million years ago [35]. The emergence of great apes date between 24 to 16 myrs, and molecular data point to a divergence of human ancestors and apes estimated to 9 to 7 myrs $[35,36]$. Thus, human and non-human primates and wild pigs occupied the same environment long before domestication of pigs occurred, potentially favoring parasite transfer from one host to another. Wild pigs were hunted by humans since the begining of the Eocene, but closer contact was established with domestication [34].

After domestication of pigs occurred, the contact among hosts favored transference of Ascaris sp. of human and pig origin, promoting adaptations to one or other host. Contemporary examples of this close contact have been recorded in South American Indian communities [37], where suckling New World wild pigs (T. pecari, P. tajacu) are adopted and fed by women (Figure 1). Some Indian groups include rituals in which pig behavior is incorporated and acted out by young warriors [38]. There are ancient cultural and religious representations of close contact of humans and pigs in Europe and Asia [34,39], including an ancient toothbrush made of pig bristles (Figure 2).

Considering the above discussions, ascarids have been found today both in wild pigs and non-human primates in natural or close to natural conditions [23,26,29]. This could have happened also in the past.

\section{Evidence from Molecular Biology}

The first attempts to separate the two species of Ascaris of human and pig origin aimed to identify specific molecular markers. Studies were mainly conducted in China, where high prevalence rates are found in both pigs and humans, and pig feces are used as fertilizers $[9,10]$. The interest on this subject increased after description of "cross infections" in North America and Denmark $[9,18,40]$.

A zoonosis is characterized when the human host is infected by a parasite of wild or domestic animal [3]. Regarding Ascaris sp. in domestic pigs, due to the anthelmintic frequency and high doses used, cases of resistance have been registered in several animals [41]. Therefore, the zoonotic potential and possible cases of worm resistance may change public health strategies to control ascariasis in human communities $[9,42]$.

Molecular epidemiology studies to distinguish the two species of Ascaris have been conducted [43]. PCR-RFLP (Polymerase Chain Reaction - Restriction Fragment Length Polymorphism) was applied to identify different restriction profiles for Ascaris sp. of both human and pig origin, using the nuclear region ITS1 (Internal Transcribed Spacer-1) as the molecular target [44]. In provinces in China, five parasite genotypes (G1-G5) for human and pig species were found using the same molecular target [45]. Although the G1 genotype is associated mainly with humans, and G3 occurs mostly in pigs, common Ascaris genotypes were found in both hosts. Intra-individual high variability in isolates of Ascaris sp. using as target the region ITS1 was found in Brazil, calling attention to the problems of using this target to genotype Ascaris spp. of human and pig origin [46].

Other molecular markers have been proposed and used to study molecular epidemiology of Ascaris spp. The mitochondrial markers (cytochrome c oxidase subunit 1 ( $\operatorname{cox} 1)$, and NADH dehydrogenase subunit 1 (nad1)) were used in samples from six Chinese provinces [47]. The authors found for the gene cox 1, 10 different haplotypes of Ascaris spp. in the human host (H1-H10), and 10 for pigs (P1-P10). For nad1 11 different haplotypes of Ascaris spp. were found in the human host (H1-H11), and 15 in pigs (P1-P15). Although the authors considered a low genetic flow between these species, results showed a common haplotype for Ascaris sp. of human and pig origin for the cox 1 gene. Microsatelites have also been used to study molecular epidemiology of Ascaris spp. showing that hybridization between worm population of human and pig origin probably occurred which may have implications for Ascaris control programs [42]. Recently, possible cases of human ascariasis from pig-derived Ascaris sp. were recorded in Japan [48]. Additionally, recent sequences available in Genbank from humans and non-human primates are identical to pig genotypes or haplotypes. In 2011 the complete mtDNA genome of A. lumbricoides was sequenced, showing that the complete $A$. lumbricoides mt genome differs from $A$. suum by only $1.9 \%$ [49]. Based on the high similarity of nucleotide and amino acid sequences of complete $A$. suum and A. lumbricoides mt genomes, the authors considered that both might represent the same species.

\section{Perspectives or utopia}

The origin of taeniid tapeworms found in humans, including Taenia solium, T. saginata, and T. asiatica was tested by application of phylogenetic systematic methods of DNA sequences [50]. Human tapeworm species are similar to the species found in felids, wild canids, and African hyenas. The typical life cycle of the taeniids involves a carnivorous definitive host and an herbivorous intermediate host; tapeworm eggs eliminated by these carnivores in the feces are ingested by herbivores. Hominids became infected, and served well as the definitive host, by eating herbivores infected with 


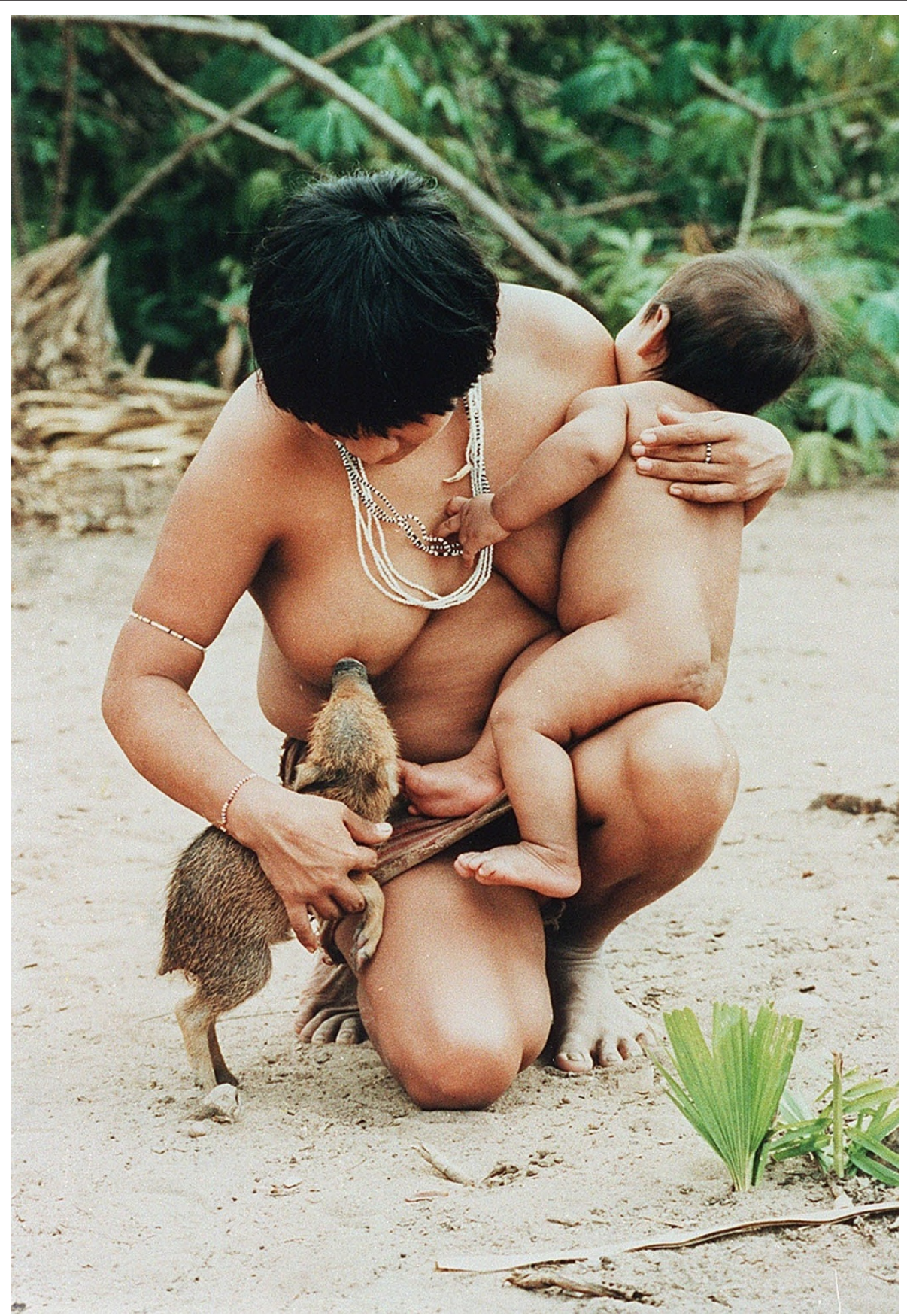

Figure 1 Native Guajá from northeastern Brazil breastfeeding a wild pig. Source: Pisco Del Gaiso, Folha de São Paulo - Brazil, 1992. The authors have received permission from the copyright holders Pisco Del Gaiso, Folha de São Paulo - Brazil to reproduce the image in this publication.

tapeworm larva. The adults usually occurred in other sympatrically occurring scavenging carnivores such as hyenas. After switching hosts, a speciation event occurred and humans maintained their own two species of Taenia. Therefore, these cestodes of humans adapted to pigs and cattle as intermediate hosts sometime after domestication of these animals. Molecular biology studies suggest that Homo erectus introduced T. asiatica in Asia, and the other human species of Taenia were introduced to the Americas only after Columbus [51-53]. Genetics and paleoparasitological data support this hypothesis due to the fact that no Taenia sp. eggs have yet been found in pre-Columbian South American archaeological material. 

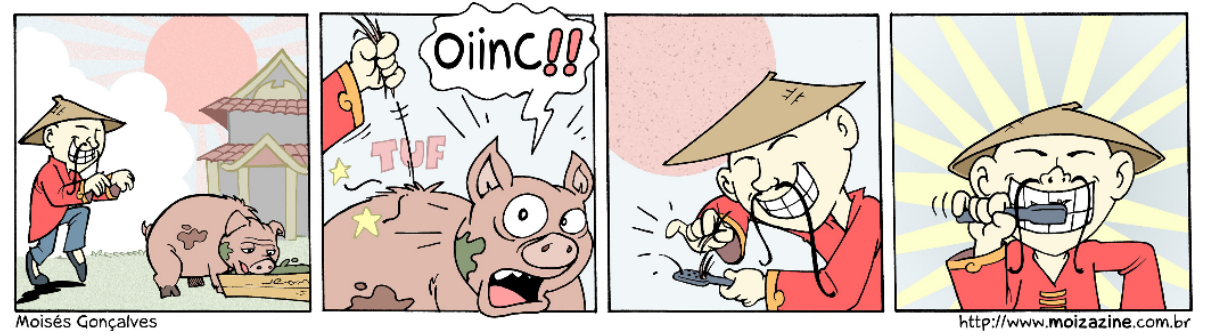

Figure 2 Toothbrush origin. The authors confirm that they have received permission from Moises Goncalves to reproduce the image in this publication. The image was originally published in http://www.moizazine.com.br.

Considering the data presented above, "the comparative method" would call for a broad study of the genetics of Ascaris spp. in modern humans and pigs from different regions, we also recommend that a broad survey of other vertebrate hosts be conducted following the Taenia sp. model (see methods in Gardner [54] and Gardner and Jimenez-Ruiz [55]). In Ascaris sp. studies it is possible to include New World and Old World archaeological material [6], and recover ancient parasite DNA to compare with modern sequences.

Molecular paleoparasitology techniques have been applied to Ascaris spp. [56-58]. However, to accumulate solid evidence more samples should be examined, as well as other molecular targets. Another difficulty is that human coprolites are found in archaeological sites in greater number than pig coprolites.

Phylogenetic relationships of nematodes classified in the Ascaridoidea were estimated by Nadler and Hudspeth [59] based on a total evidence parsimony analysis of a combination of morphology and one mitochondrial and two nuclear genes. Their study shows that $A$. lumbricoides and A. suum are sister taxa that share a most recent common ancestor with Parascaris equorum the large ascarid of horses. Because these species share a most recent common ancestor, there is no way to place either A. suum or A. lumbricoides in a position as "the more derived species". Nadler and Hudspeth [59] note that in their study, A. lumbricoides had 7 unambigious molecular autapomorphies while $A$. suum had one rDNA autapomorphy and that the level of genetic differentiation (genetic distance) was low, showing the smallest pairwise distance among all taxa included in their analysis.

\section{Conclusions}

The origin of Ascaris spp. is still not well understood. Results obtained from experimental infections and molecular methods have been inconclusive, and before this time, none of the published studies answered the question of whether A. lumbricoides and A. suum are truly distinct species.
Mitochondrial markers in modern parasite samples from humans and pigs from Brazil, collected in rural and urban areas, as well as in American Native Indian communities, were analyzed. All samples were collected from people in close contact with pigs and data showed common haplotypes in Ascaris sp. derived both from human and pig hosts. Taking into account the history of close contact of humans and wild pigs, estimated at about 10,000 years before present, the verified nematode crossinfections between humans and pigs, and the documented hybridization that occurred between A. lumbricoides and $A$. suum, together with the recent insights about high levels of genetic similarity between the complete mtDNA genomes of $A$. lumbricoides and A. suum $[6,9-11,18,40,42,59]$ we conclude that only a single interbreeding population of Ascaris exists, and the genotypic and phenotypic differences are only manifested at the population level. The populations occurring in humans or pigs have only slight phenotypical and genotypic adaptative changes; however, with a single natural history. Thus, we recommend synonymizing these two species, with the name Ascaris lumbricoides Linnaeus 1758 taking priority over Ascaris suum Goeze 1782.

\section{Acknowledgements}

Our work was supported by the Brazilian agencies Conselho Nacional de Pesquisa e Desenvolvimento Tecnológico (CNPq), Fundação Carlos Chagas Filho de Amparo à Pesquisa do Estado do Rio de Janeiro (FAPERJ), and Coordenação de Aperfeiçoamento de Pessoal de Nível Superior (CAPES). In addition, support to S. L. Gardner during the development of this paper was provided by US. National Science Foundation Grant Nos. DBI-0717214 and DBI-0646356. We would also like to thank reviewers for their contributions to this paper.

\section{Author details}

${ }^{1}$ Departamento de Microbiologia e Parasitologia, Instituto Biomédico, Universidade Federal Fluminense, MIP-UFF, Rua Professor Hernani Melo 101, São Domingos, Niterói, 24210-130, RJ, Brazil. ²School of Biological Sciences, University of Nebraska- Lincoln, Harold W. Manter Laboratory of Parasitology W 529 Nebraska Hall University of Nebraska-Lincoln Lincoln, Nebraska 685880514 USA. ${ }^{3}$ School of Natural Resource Sciences, University of Nebraska at Lincoln, 6940 Van Dorn Street Ste 105, Lincoln, Nebraska 68506, USA.

${ }^{4}$ Intituto Oswaldo Cruz, Fundação Oswaldo Cruz, Av. Brasil 4365,

Manguinhos, Rio de Janeiro, 21045-900, RJ, Brazil. ' Escola Nacional de Saúde Pública, Fundação Oswaldo Cruz, Rua Leopoldo Bulhões 1480, Manguinhos, Rio de Janeiro, 21041-210, RJ, Brazil. 


\section{Authors' contributions}

$D L$ wrote the first draft, and $D L$ and $A M I$ were responsible for molecular biology studies; AA, SLG, and KR discussed paleoparasitology, parasitism, and roundworm and whipworm evolution; $\mathrm{DL}$ was responsible for the main results; all authors approved the final version of the manuscript.

\section{Authors' information}

DL, Sc.D., is Associate Professor, publishing on molecular biology and paleoparasitology; AMI, Sc.D., is a Research Assistant, publishing on molecular biology and paleoparasitology; SLG, Ph.D., Curator and Professor, Harold W. Manter Laboratory of Parasitology, KR, Ph.D., Fulbright Commission Senior Specialist in Botanical Archaeology, and Professor in Forensic Science; AA, MD, Sc.D., Senior Researcher, paleoparasitology specialist since 1980.

\section{Competing interests}

The authors declare that they have no competing interests.

Received: 2 January 2012 Accepted: 20 February 2012 Published: 20 February 2012

\section{References}

1. Maggenti, Nemata AR: Higher Classification. In Manual of agricultural nematology. Edited by: Nickle WR, Dekker M. New York; 1991:147-187.

2. Chowdhury N, Aguirre AA: Helminths of wildlife Enfield, Science Publishers Inc; 2001.

3. Acha PN, Szyfress B: Zoonoses and communicable diseases common to man and animals. 3 edition. Scientific and Technical Publication Washington, Pan American Health Organization; 2003.

4. Poinar G, Boucot AJ: Evidence of intestinal parasites of dinosaurs. Parasitology 2006, 133:245-249.

5. Fonseca O: Parasitismo e migrações humanas pré-históricas: contribuições da parasitologia para o conhecimento das origens do homem americano Rio de Janeiro: Mauro Familiar; 1972

6. Gonçalves MLC, Araújo A, Ferreira LF: Human intestinal parasites in the past: new fidings and a review. Mem Inst Oswaldo Cruz 2003, 98(Suppl 1):103-118.

7. Loreille O, Bouchet F: Evolution of ascariasis in human and pigs: a multidisciplinary approach. Mem Inst Oswaldo Cruz 2003, 98(Suppl 1):39-46.

8. Leles D, Reinhard K, Fugassa M, Ferreira LF, Iniguez AM, Araújo A: A parasitological paradox: why is ascarid infection so rare in the prehistoric Americas? J Archaeol Sci 2010, 37:1510-1520.

9. Anderson TJC: The dangers of using single locus markers in parasite epidemiology: Ascaris as a case study. Trends Parasitol 2001, 17:183-188.

10. Peng W, Yuan K, Hu M, Gasser RB: Recent insights into the epidemiology and genetics of Ascaris in China using molecular tools. Parasitology 2007, 134:325-330.

11. Crompton DWT: Ascaris and ascariasis. Adv Parasitol 2001, 48:286-375.

12. Ansel $M$, Thibaut $M:$ Value of the specific distinction between Ascaris lumbricoides Linnaeus 1758 and Ascaris suum Goeze 1782. Int J Parasitol 1973, 3:317-319.

13. Takata I: Experimental infection of man with Ascaris of man and the pig. Kitasato Arch Exp Med 1951, 23:49-59.

14. Galvin TJ: Development of human and pig Ascaris in the pig and rabbit J Parasitol 1968, 54:1085-1091.

15. Crewe W, Smith DH: Human infection with pig Ascaris (A. suum). Ann Trop Med Parasitol 1971, 65:85.

16. Lord WD, Bullock WL: Swine Ascaris in humans. N Engl J Med 1982, 306:113.

17. Jungersen G, Eriksen L, Nielsen CG, Roepstorff A, Nansen P: Experimental transfer of Ascaris suum from donor pigs to helminth naïve pigs. J Parasitol 1996, 82:752-756.

18. Anderson TJC: Ascaris infections in humans from North America: molecular evidence for cross-infection. Parasitology 1995, 110:215-219.

19. Peng W, Yuan K, Hu M, Peng G, Zhou X, Hu N, Gasser RB: Experimental infections of pigs and mice with selected genotypes of Ascaris. Parasitology 2006, 133:651-657.

20. Confalonieri U: Paleopidemiologia de T. trichiura na América. In Paleoparasitologia no Brasil. Edited by: Ferreira LF, Araújo A, Confalonieri U. Rio de Janeiro: PEC/ENSP; 1998:120-137.

21. Kliks MM: Helminths as heirlooms and souvenirs: a review of New World paleoparasitology. Parasitol Today 1990, 6:93-100.
22. Mutani A, Rhynd K, Brown G: A preliminary investigation on the gastrointestinal helminths of the Barbados green monkey, Cercopithecus aethiops sabaeus. Rev Inst Med Trop Sao Paulo 2003, 45:193-195.

23. Hope K, Goldsmith ML, Graczyk T: Parasitic health of olive baboons in Bwindi Impenetrable National Park, Uganda. Vet Parasitol 2004, 122:165-170

24. Jones-Engel L, Engel GA, Schillaci MA, Kyes K, Froehlich JY, Paputungan M, Kyes RC: Prevalence of enteric parasites in pet Macaques in Sulawesi, Indonesia. Am J Primatol 2004, 62:71-82

25. Gillespie TR, Greiner EC, Chapman CA: Gastrointestinal parasites of the Colubus monkeys of Uganda. J Parasitol 2005, 91:569-573.

26. Eckert KA, Hahn NE, Genz AK, Dawn M, Stuart MD, Averbeck GA, Stromberg BE, Markowitz H: Coprological surveys of Alouatta pigra at two sites in Belize. Int J Primatol 2006, 27:227-238.

27. Nejsum P, Bertelsen MF, Betson M, Stothard JR, Murrell KD: Molecular evidence for sustained transmission of zoonotic Ascaris suum among zoo chimpanzees (Pan troglodytes). Vet Parasitol 2010, 171:273-276.

28. Lim Y, Ngui R, Shukri J, Rohela M, Mat Naim HR: Intestinal parasites in various animals at a zoo in Malaysia. Vet Parasitol 2008, 157:154-159.

29. Teichroeb JA, Kutz SJ, Parkar, Thompson ARC, Sicotte P: Ecology of the gastrointestinal parasites of Colobus vellerosus at Boabeng-Fiema, Ghana: possible anthropozoonotic transmission. Am J Phys Antropol 2009, 140:498-507.

30. Shalaby HA, Abdel-Shafy S, Derbala AA: The role of dogs in transmission of Ascaris lumbricoides for humans. Parasitol Res 2010, 106:1021-1026.

31. Carlos N, Tantaleán M, Leguía VG, Paloma Alcázar P, Donadi R: Frecuencia de helmintos en huanganas silvestres (Tayassu pecari, Link 1795) residentes en áreas protegidas del departamento de Madre de Dios Perú. Neotrop Helminthol 2008, 2:48-53.

32. Regolin AL, Oliveira CHS, Carvalho-Pinto CJ: Primeira ocorrência de Ascaris suum em queixada (Tayassu pecari: Tayassuidae), Santa Catarina, Brasil [abstract]. Rev Patol Trop 2009, 38(Suppl 2):s1092.

33. Bouchet F, Baffier D, Girard M, Morel P, Paicheler JC, David F: Paléoparasitologie en contexte pléistocène: premières observations à la Grande Grotte d'Arcy-sur-Cure (Yonne), France. CR Acad Sci Paris 1996, 319:147-151

34. Albarella U: Pigs and humans 10,000 years of interaction Oxford: University Press; 2007.

35. Benton MJ: Vertebrate Paleontology Oxford, Wiley-Blackwell; 2004.

36. Campbell BG, Loy JD, Cruz-Uribe K: Humankind Emerging Boston, Pearson Education Inc; 2006

37. Coimbra Jr, Ventura R: Parasitismo intestinal entre o grupo indígena Zoró, Estado do Mato Grosso. Cad Saúde Pública 1991, 7:100-103.

38. Fausto C: Banquete de gente: comensalismo e canibalismo na Amazônia. MANA 2002, 8:7-44.

39. Donkin RA: The peccary-with observations on the introduction of pigs to the New World. Amer Philosophical Society 1985, 75:1-152.

40. Nejsum P, Parker ED Jr, Frydenberg J, Roepstorff A, Boes J, Haque R, Astrup I, Prag J, Skov Sørensen UB: Ascariasis is a Zoonosis in Denmark. Clin Microbiol 2005, 43:1142-1148.

41. Larsen M: Biological control of helminths. Int J Parasitol 1999, 29:139-146.

42. Criscione CD, Anderson JD, Sudimack D, Peng W, Jha B, WilliamsBlangero $S$, Anderson TJ: Disentangling hybridization and host colonization in parasitic roundworms of humans and pigs. Proc Biol Sci 2007, 274:2669-2677.

43. Anderson TJC, Romero-Abal M, Jaenike J: Genetic structure and epidemiology of Ascaris populations: patterns of host affiliation in Guatemala. Parasitology 1993, 107:319-334.

44. Zhu X, Chilton NB, Jacobs DE, Boes J, Gasser RB: Characterisation of Ascaris from human and pig hosts by nuclear ribosomal DNA Sequences. Int $J$ Parasitol 1999, 29:469-478.

45. Peng W, Yuan K, Zhou X, Hu M, EL-Osta YG, Gasser RB: Molecular epidemiological investigation of Ascaris genotypes in China based on single-strand conformation polymorphism analysis of ribosomal DNA. Electrophoresis 2003, 24:2308-2315.

46. Leles $D$, Araújo A, Vicente ACP, Iñiguez AM: ITS1 intra-individual variability of Ascaris isolates from Brazil. Parasitol Int 2010, 59:93-96.

47. Peng W, Yuan K, Hu M, Zhou X, Gasser RB: Mutation scanning-coupled analysis of haplotypic variability in mitochondrial DNA regions reveals low gene flow between human and porcine Ascaris in endemic regions of China. Electrophoresis 2005, 26:4317-4326 
48. Arizono N, Yoshimura Y, Tohzaka N, Yamada M, Tegoshi T, Onishi K, Uchikawa R: Ascariasis in Japan: is pig-derived Ascaris infecting humans? $J$ Infect Dis 2010, 63:447-448.

49. Liu Guo-Hua, Wu Chang-Yi, Song Hui-Qun, Wei Shu-Jun, Xu Min-Jun, Lin Rui-Qing, Zhao Guang-Hui, Huang Si-Yang, Zhu Xing-Quan: Comparative analyses of the complete mitochondrial genomes of Ascaris lumbricoides and Ascaris suum from humans and pigs. Gene 2012, 492:110-116.

50. Hoberg EP, Alkire NL, Queiroz A, Jones A: Out of Africa: origins of the Taenia tapeworms in human. Proc R Soc Lond B 2001, 268:781-787.

51. Nakao M, Okamoto M, Sako Y, Yamasaki H, Nakayak, Ito A: A phylogenetic hypothesis for the distribution of two genotypes of the pig tapeworm Taenia solium worldwide. Parasitology 2002, 124:657-662.

52. Hoberg EP: Phylogeniy of Taenia: species definitions and origins of human parasites. Parasitol Int 2006, 55(Suppl 1):23-30.

53. Martinez-Hernandez F, Jimenez-Gonzales DE, Chenillo P, Alonso Fernandez C, Maravilla P, Flisser A: Geographical widespread of two lineages of Taenia solium due to human migrations: can population genetic analysis strengthen this hypothesis? Infect Genet Evol 2009, 9:1108-1114.

54. Gardner SL: Essential techniques for collection of parasites during surveys of mammals. In Measuring and Monitoring Biological DiversityStandard Methods for Mammals. Edited by: Wilson D, Cole R, Nichols JD, Rudran R, Foster M. Washington: Smithsonian Institution Press; 1996:291-298.

55. Gardner SL, Jiménez-Ruiz FA: Methods of endoparasite analysis. In Ecological and Behavioral Methods for the Study of Bats. Edited by: Kunz T, Parsons S. Maryland, Johns Hopkins University Press; 2009:795-805.

56. Loreille $\mathrm{O}$, Roumat $\mathrm{E}$, Verneau O, Bouchet $\mathrm{F}$, Hänni C: Ancient DNA from Ascaris: extraction amplification and sequences from eggs collected in coprolites. Int J Parasitol 2001, 31:1101-1106.

57. Leles D, Araújo A, Ferreira LF, Vicente ACP, Iñiguez AM: Molecular paleoparasitological diagnosis of Ascaris sp from coprolites: new scenery of ascariasis in pre-Colombian South America times. Mem Inst Oswaldo Cruz 2008, 103:106-108.

58. CS Oh, Seo Min, Lim Nam Jin, Lee Sang Jun, Lee Eun-Joo, Lee Soong Deok, Shin Dong Hoon: Paleoparasitological report on Ascaris aDNA from an ancient East Asian sample. Mem Inst Oswaldo Cruz 2010, 105:225-228.

59. Nadler SA, Hudspeth DSS: Phylogeny of the ascaridoidea (nematoda: ascaridida) based on three genes and morphology: hypotheses of structural and sequence evolution. J Parasitol 2000, 86:380-393.

doi:10.1186/1756-3305-5-42

Cite this article as: Leles et al:: Are Ascaris lumbricoides and Ascaris suum a single species? Parasites \& Vectors 2012 5:42.

\section{Submit your next manuscript to BioMed Central and take full advantage of:}

- Convenient online submission

- Thorough peer review

- No space constraints or color figure charges

- Immediate publication on acceptance

- Inclusion in PubMed, CAS, Scopus and Google Scholar

- Research which is freely available for redistribution

Submit your manuscript at www.biomedcentral.com/submit
Biomed Central 